\title{
IDENTIFIKASI KAWASAN PERMUKIMAN KUMUH DI KAWASAN WURING, KABUPATEN SIKKA, NUSA TENGGARA TIMUR
}

\author{
Kristiana Bebhe ${ }^{1}$, Yuliana Bhara Mberu ${ }^{2}$ \\ 1,2. Program Studi Arsitektur, Fakultas Teknik, Universitas Katolik Widya Mandira, \\ Penfui, Kupang \\ Email: ${ }^{1}$ kristianabebhe@yahoo.com, ${ }^{2}$ liamberu31@gmail.com
}

\begin{abstract}
Abstrak
Kawasan Wuring yang terletak di Kabupaten Sikka dan didominasi oleh Suku Bajo mempunyai isu menyangkut kawasan permukiman kumuh. Identifikasi kawasan permukiman kumuh ini dilakukan untuk menjadi data dasar dan informasi terkait kawasan kumuh bagi pemerintah daerah, perencana, perancang dan pengembang kawasan dalam membuat keputusan untuk menangani kawasan permukiman kumuh. Penentuan kriteria kawasan permukiman kumuh mempertimbangkan berbagai aspek seperti kondisi infrastruktur, kepadatan bangunan, kondisi kependudukan dan legalitas lahan. Tujuan dari penelitian ini adalah melakukan identifikasi dan penilaian lokasi kawasan permukiman kumuh di kawasan Wuring, Kabupaten Sikka, Provinsi Nusa Tenggara Timur serta membuat rekomendasi penanganan masalah permukiman kumuh tersebut. Metode penelitian yang digunakan adalah metode penelitian deduktif yang berpedoman pada kriteria-kriteria yang terdapat pada Buku Pedoman Identifikasi Permukiman Kumuh Direktorat Pengembangan Permukiman, Direktorat Jenderal Cipta Karya, Departemen Pekerjaan Umum. Hasil penelitian menunjukkan kawasan Wuring memiliki tingkat kekumuhan yang tinggi dan status kepemilikan lahan tidak legal yang tinggi.
\end{abstract}

Kata kunci: identifikasi, permukiman kumuh, kawasan wuring.

\section{Abstract}

Title: Identification of Slum Settlement in Wuring Area, Sikka District, East Nusa Tenggara

The Wuring area, located in Sikka regency East Nusa Tenggara province. This settlement is dominated by the Bajo tribe and considered as a slum area. The identification of slum areas was carried out in order to provide basic data and slums-related information for local governments, planners, designers and area developers in making decisions or considerations in handling the slum settlement program. Determine criteria for slum areas was conducted by considering various aspects or dimensions such as the suitability of the location allotment related with spatial planning, land status (ownership), location, level of population and building density and physical, social, economic and cultural conditions of the local community. The study aims to identify and assess the location of slum areas in the Wuring area and furthermore recommend how the handling of this slum areas. For this purpose, the deductive research method using the criterias based on the Slum Settlement Identification Handbook issued by the Directorate of Settlement Development, Directorate General of Human Settlements, Indonesian Ministry of Public Works. The result of the study is that in the Wuring area has high level of slums and illegal land status.

Keywords: identification, slum areas, Wuring area.

\section{Pendahuluan}

Kawasan permukiman Wuring yang terletak di Kabupaten Sikka, Provinsi Nusa Tenggara Timur didominasi oleh Suku Bajo. Kawasan ini mempunyai isu menyangkut kawasan permukiman kumuh. Walaupun masih dalam taraf jumlah populasi yang cenderung sedikit, tidak membuat kabupaten ini terlepas dari permasalahan permukiman kumuh.

Dampak dari permasalahan kawasan permukiman kumuh selalu berpengaruh pada kesehatan. Pengaruh buruk yang dihasilkan 
berupa kualitas hidup penduduk yang menurun hingga wabah penyakit yang marak. Oleh sebab itu, untuk mencegah segala dampak negatif yang akan terjadi, maka dibutuhkan penanganan-penanganan yang baik dan sesuai dengan standar yang ada serta tetap mengacu pada peraturan-peraturan yang mengatur hal tersebut.

Kawasan permukiman Wuring berada di pesisir pantai memiliki beragam masalah permukiman kumuh, diantaranya kepadatan bangunan yang cukup tinggi, letak bangunan hunian yang tidak teratur, kondisi jalan lingkungan yang tidak memiliki drainase, minimnya penyediaan air bersih, pengelolaan air limbah tidak sesuai dengan persyaratan teknis dan tidak tersedianya sarana prasarana pengelolaan sampah, sehingga sampahsampah dibuang sembarangan pada pekarangan dan area pantai.

Tujuan melakukan identifikasi kawasan permukiman kumuh pada kawasan Wuring adalah untuk menjadi data dasar dan informasi terkait kawasan kumuh, terutama bagi pemerintah, perencana dan perancang serta pengembang kawasan saat membuat keputusan atau pertimbangan penanganan kawasan permukiman kumuh Wuring. Sehingga dalam menentukan kriteria kawasan permukiman kumuh dilakukan dengan mempertimbangkan berbagai aspek yang sesuai dengan standart yang berlaku.

\section{Metode Penelitian}

Metode penelitian yang digunakan adalah metode deduktif, dengan menggunakan kriteria-kriteria pada Buku Pedoman Identifikasi Permukiman Kumuh yang diterbitkan oleh Direktorat Pengembangan Permukiman, Direktorat Jenderal Cipta Karya, Departemen Pekerjaan Umum. Pelaksanaan identifikasi ini dilaksanakan di kawasan Wuring, Kabupaten Sikka. Mengatasi permasalahan yang dihadapi, diawali dengan kegiatan persiapan dan dilanjutkan dengan kegiatan observasi lokasi dan yang terakhir adalah penentuan lokasi kawasan kumuh, apakah wilayah ini termasuk dalam kategori permukiman kumuh ringan, sedang atau berat.

\section{Metode Pengumpulan Data}

Kegiatan pengumpulan data dilakukan melalui survey dengan menggunakan 2 (dua) metode pengumpulan data, yakni survey data instansional dan survey lapangan.

Kebutuhan data penelitian meliputi data primer dan data sekunder. Data primer yang dibutuhkan antara lain data Prasarana Sarana dan Utilitas (PSU) dan data penggunaan lahan. Sedangkan data sekunder yang akan dikumpulkan antara lain adalah regulasi - regulasi yang mengatur atau dasar - dasar hukum, dokumen Rencana Tata Ruang Wilayah (RTRW) Provinsi Nusa Tenggara Timur, dokumen Rencana Tata Ruang Wilayah (RTRW) Kabupaten Sikka, studi-studi terdahulu terkait dengan kawasan perencanaan dan juga dokumen lain yang terkait.

\section{Metode Pelaksanaan Pekerjaan}

Metode pelaksanaan dalam pekerjaan identifikasi permukiman kumuh ini adalah sebagai berikut:

Tahap persiapan terdiri dari:

1. Tahap survey dan observasi

2. Identifikasi lokasi

3. Identifikasi kondisi kekumuhan

4. Identifikasi legalitas lahan

5. Identifikasi pertimbangan lain

6. Penilaian lokasi

Penilaian lokasi dilakukan untuk menilai:

1. Kondisi kekumuhan Aspek permasalahan kekumuhan terdiri atas:

- Klasifikasi kumuh kategori ringan

- Klasifikasi kumuh kategori sedang

- Klasifikasi kumuh kategori berat

2. Legalitas lahan Aspek legalitas lahan terdiri atas:

- Klasifikasi status lahan legal

- Klasifikasi status lahan tidak legal

3. Pertimbangan lain Aspek pertimbangan lain dengan klasifikasi:

- Kategori rendah 
- Kategori sedang

- Kategori tinggi

Kegiatan penilaian dilakukan dengan cara melakukan pembobotan dengan melihat masing-masing kriteria. Fokus kegiatan identifikasi kawasan kumuh di Kabupaten Sikka adalah kawasan Wuring pada RT 025RT 038/ RW 007 Kecamatan Alok Barat, Kelurahan Wolomarang. Berdasarkan SK Bupati lokasi permukiman kumuh di Kabupaten Sikka khususnya Kawasan Wuring adalah $14.36 \mathrm{Ha}$.

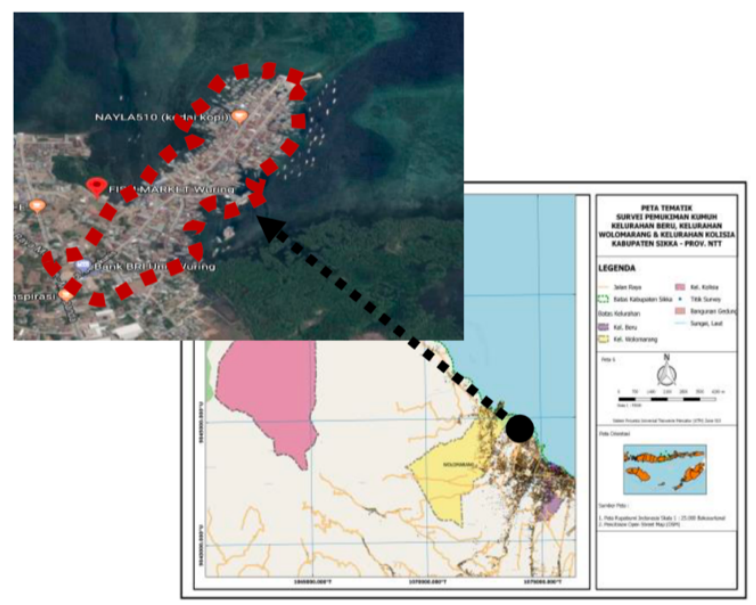

Gambar 1. Peta delineasi penelitian Sumber: Analisis peneliti dan Google Earth

\section{Hasil dan Pembahasan}

\section{Tipologi Kawasan Permukiman Kumuh Wuring}

Tipologi kawasan permukiman kumuh Wuring adalah permukiman kumuh nelayan dan permukiman kumuh daerah pasang surut.

\section{Fakta dan Analisis}

Dalam pelaksanaan penyusunan identifikasi permukiman kumuh dilakukan dengan melakukan survey pada lokasi kajian kemudian dianalisis untuk menentukan tipologi dan rencana pengembangan.

\section{Identifikasi Kawasan Permukiman Kumuh \\ Wilayah identifikasi kawasan kumuh adalah Kabupaten Sikka, Kecamatan Alok Barat, Kelurahan Wolomarang, kawasan Wuring}

pada RT 025-RT 038/ RW007 dengan Luasan 14,36 Ha.

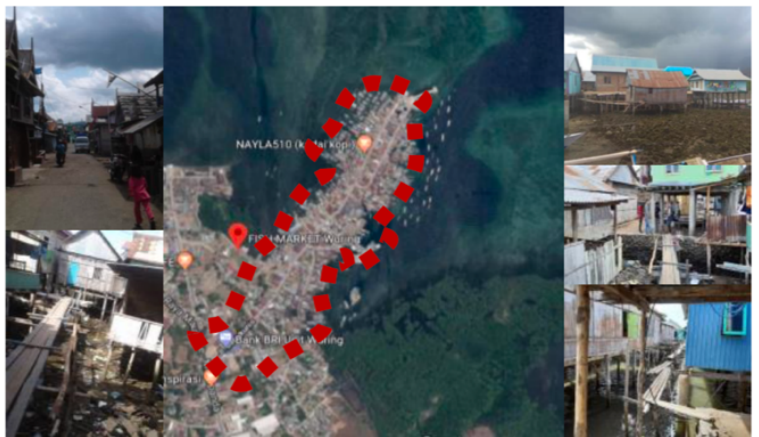

Gambar 2. Gambaran kondisi permukiman kumuh di kawasan Wuring

Sumber: Google Earth dan hasil survey, 2019

\section{Kondisi Bangunan Gedung}

Kondisi mayoritas bangunan hunian pada lokasi tidak teratur, bangunan hunian memiliki material alas, atap dan dinding non permanen. Sedangkan lokasi permukiman memiliki kepadatan bangunan yang cukup tinggi dengan berdiri pada tepi pantai.

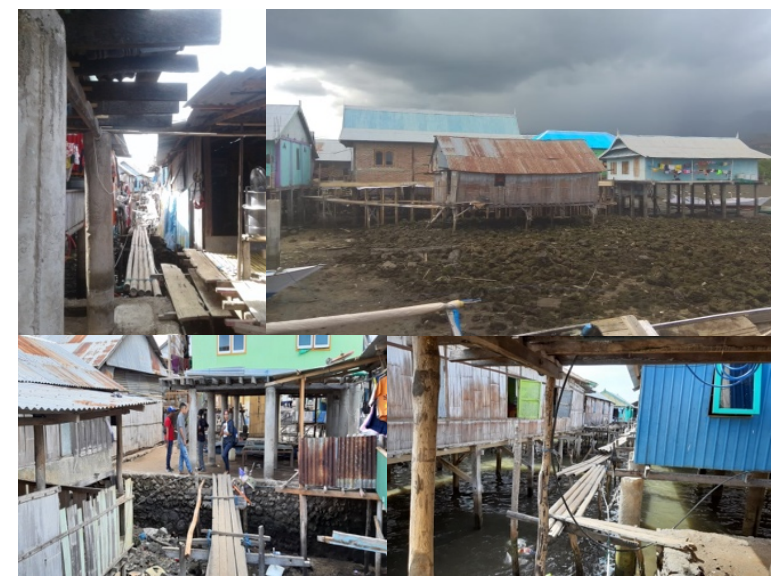

Gambar 3. Kondisi bangunan gedung pada kawasan Wuring

Sumber: Hasil survey, 2019

\section{Kondisi Jalan Lingkungan}

Kondisi sebagian jalan lingkungan memiliki kualitas permukaan jalan yang baik, namun jalan lingkungan yang dibangun tidak disertakan dengan drainase/saluran air sehingga saat hujan air mengikis sebagian jalan. Sebagian jalan lingkungan dibuat dengan menggunakan kayu atau bambu oleh 
masyarakat sendiri untuk dapat terakses langsung dengan rumah mereka.
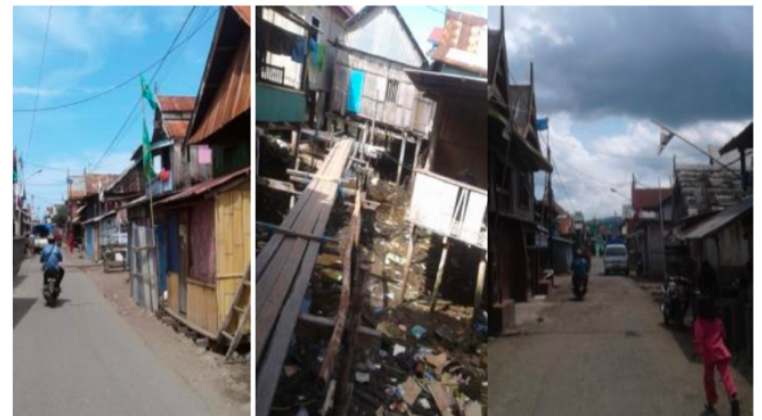

Gambar 4. Kondisi jalan lingkungan di kawasan Wuring

Sumber: Hasil survey, 2019

\section{Kondisi Drainase Lingkungan}

Jalan lingkungan tidak dilengkapi dengan drainase.

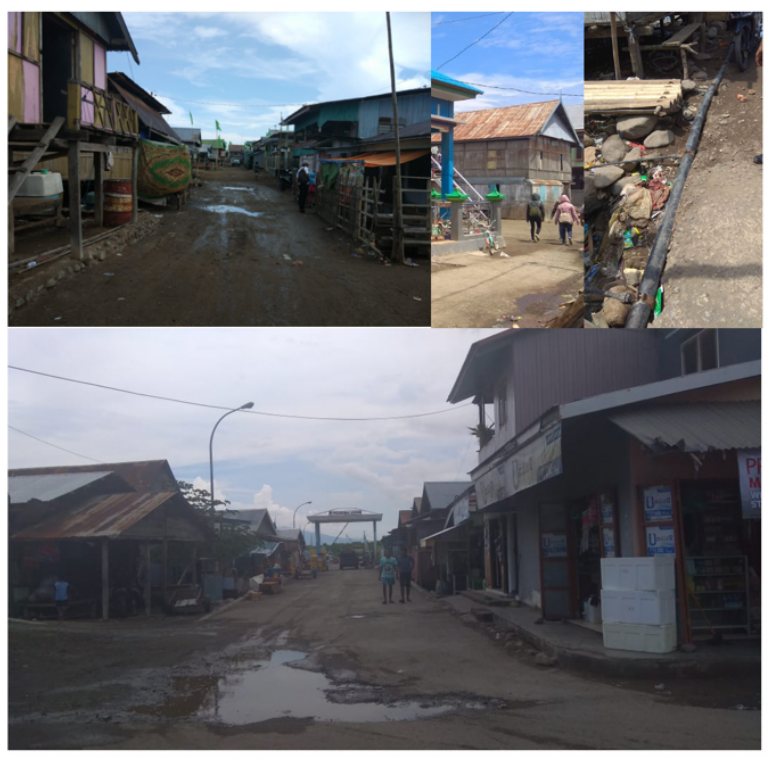

Gambar 5. Kondisi drainase lingkungan kawasan Wuring

Sumber: Hasil Survey, 2019

\section{Kondisi Penyediaan Air Minum}

Akses air minum pada lokasi menggunakan sumur dan pelayanan dari PDAM. Mayoritas belum memenuhi kebutuhan air bersih (601t/hari), 1 unit terpasang PDAM melayani 3-4 KK sehingga seringkali masyarakat masih membeli air dari mobil tangki untuk memenuhi kebutuhannya.

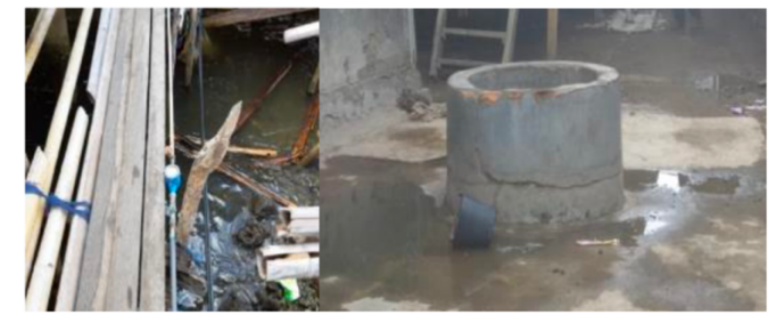

Gambar 6. Kondisi penyediaan air minum di kawasan Wuring

Sumber: Hasil survey, 2019

\section{Kondisi Pengelolaan Air Limbah}

Limbah yang dihasilkan dari rumah tangga langsung dibuang ke pantai tanpa penyaringan. Sedangkan untuk pembuangan WC, mayoritas kloset terhubung septictank. Pengolahan limbah sebagian telah terlayani IPAL (Instalasi Pengolahan Air Limbah) komunal.

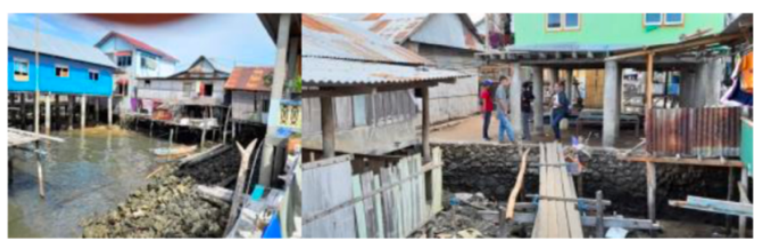

Gambar 7. Kondisi pengelolaan air limbah di kawasan Wuring

Sumber: Hasil survey, 2019

\section{Kondisi Pengelolaan Persampahan}

Tidak ada sarana dan prasarana pengelolaan sampah pada kawasan. Sampah-sampah dibuang sembarangan pada pekarangan dan area pantai tempat masyarakat menetap.

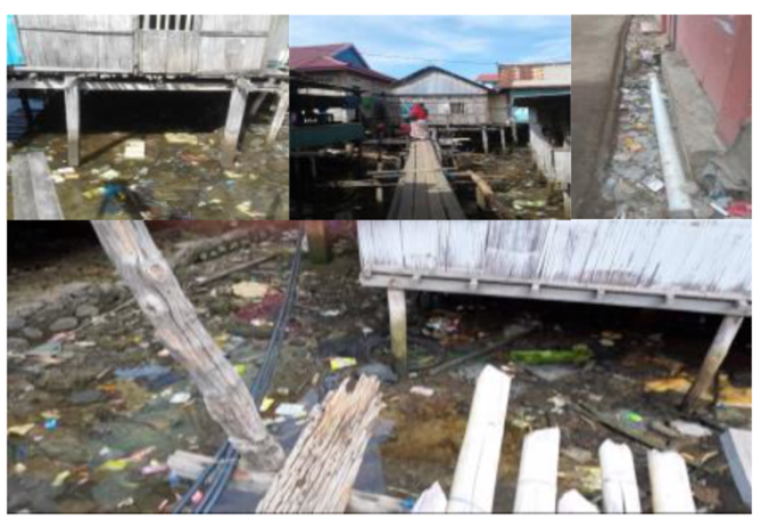

Gambar 8. Kondisi penyediaan pengelolaan persampahan di kawasan Wuring Sumber: Hasil survey, 2019 
7. Kondisi Proteksi Kebakaran

Pada kawasan ini tidak disediakan sarana dan prasarana proteksi kebakaran.

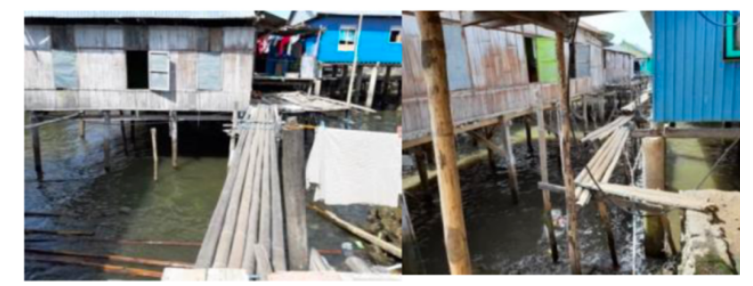

Gambar 9. Kondisi kawasan perumahan tanpa proteksi pebakaran

Sumber: Hasil survey, 2019
Format Numerik Lokasi Perumahan Kumuh dan Permukiman Kumuh Wuring Data umum kawasan Wuring ditunjukkan dalam tabel berikut.

\section{Tabel. 1. Data umum kawasan Wuring}

\begin{tabular}{|l|l|l|l|}
\hline Kawasan & :Wuring & Luasan SK & $14,36 \mathrm{Ha}$ \\
\hline Kelurahan & :Wolomarang & Luasan Verifikasi & $14,36 \mathrm{Ha}$ \\
\hline Kecamatan & :Alok Barat & Jumlah Bangunan & \\
\hline Kabupaten & $:$ Sikka & Jumlah Penduduk & 2227 Jiwa \\
\hline Provinsi & :NTT & Jumlah KK & $565 \mathrm{KK}$ \\
\hline
\end{tabular}

Sumber: Hasil survey, 2019

\section{Data Numerik Parameter Kekumuhan}

Data numerik dan parameter kekumuhan di kawasan Wuring dapat dilihat pada tabel berikut.

Tabel 2. Data numerik parameter kekumuhan

\begin{tabular}{|c|c|c|c|}
\hline 1. & $\begin{array}{l}\text { Aspek kondisi bangunan gedung } \\
\text { a. Ketidakteraturan bangunan } \\
\text { b. Tingkat kepadatan bangunan } \\
\text { c. Persyaratan teknis bangunan }\end{array}$ & $\begin{array}{l}\text { Jumlah bangunan tidak teratur } \\
\text { Luas kawasan dengan } \\
\text { kepadatan }>200 / 250 \text { unit/Ha } \\
\text { Jumlah bangunan tidak sesuai } \\
\text { teknis }\end{array}$ & $\begin{array}{l}\text { Numerik } \\
580 \text { unit } \\
14,36 \text { Ha } \\
531 \text { unit }\end{array}$ \\
\hline 2. & $\begin{array}{l}\text { Aspek kondisi jalan lingkungan } \\
\text { a. Cakupan pelayanan jalan lingkungan } \\
\text { b. Kualitas permukaan jalan lingkungan }\end{array}$ & $\begin{array}{l}\text { Panjang jalan ideal (standar } \\
\text { minimal) } \\
\text { Panjang jalan eksisting } \\
\text { Panjang jalan dengan } \\
\text { permukaan retak dan } \\
\text { perubahan bentuk }\end{array}$ & $\begin{array}{l}920 \mathrm{~m} \\
920 \mathrm{~m}\end{array}$ \\
\hline 3. & $\begin{array}{l}\text { Aspek kondisi penyediaan air minum } \\
\text { a. Ketersediaan akses aman air minum } \\
\text { b. Tidak terpenuhinya kebutuhan air minum }\end{array}$ & $\begin{array}{l}\text { Jumlah KK tidak terakses air } \\
\text { minum berkualitas } \\
\text { Jumlah KK tidak terpenuhi air } \\
\text { minum cukup }\end{array}$ & $\begin{array}{l}280 \mathrm{KK} \\
280 \mathrm{KK}\end{array}$ \\
\hline 4. & $\begin{array}{l}\text { Aspek kondisi drainase lingkungan } \\
\text { a. Ketidakmampuan mengalirkan limpasan } \\
\text { air } \\
\text { b. Ketidaktersediaan drainase } \\
\text { c. Kualitas konstruksi drainase }\end{array}$ & 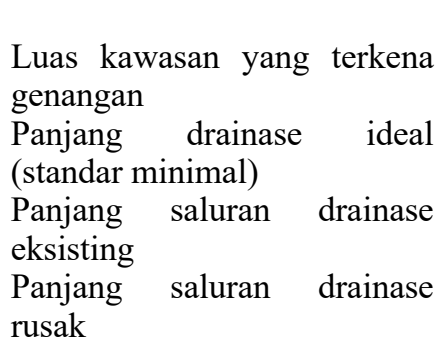 & $\begin{array}{l}460 \mathrm{~m} ' \\
920 \mathrm{~m} \\
-\end{array}$ \\
\hline 5. & $\begin{array}{l}\text { Aspek kondisi pengelolaan air limbah } \\
\text { a. Sistem pengelolaan air limbah tidak } \\
\text { sesuai standar teknis } \\
\text { b. Prasarana dan sarana pengelolaan air } \\
\text { limbah tidak sesuai dengan persyaratan } \\
\text { teknis }\end{array}$ & $\begin{array}{l}\text { Jumlah KK tidak terakses } \\
\text { sistem air limbah } \\
\text { Standar jumlah KK dengan } \\
\text { sarana dan prasarana air } \\
\text { limbah tidak sesuai standar } \\
\text { teknis }\end{array}$ & $\begin{array}{l}565 \mathrm{KK} \\
565 \mathrm{KK}\end{array}$ \\
\hline
\end{tabular}




\begin{tabular}{|c|c|c|c|}
\hline 6. & $\begin{array}{l}\text { Aspek kondisi pengelolaan persampahan } \\
\text { a. Prasarana dan sarana persampahan tidak } \\
\text { sesuai dengan persyaratan teknis } \\
\text { b. Sistem pengelolaan persampahan yang } \\
\text { tidak sesuai standar teknis }\end{array}$ & $\begin{array}{l}\text { Jumlah KK dengan sarana } \\
\text { prasarana pengolahan sampah } \\
\text { yang tidak sesuai standar } \\
\text { teknis } \\
\text { Jumlah KK dengan sistem } \\
\text { pengolahan sampah tidak } \\
\text { sesuai standar teknis }\end{array}$ & $565 \mathrm{KK}$ \\
\hline 7. & $\begin{array}{l}\text { Aspek kondisi proteksi kebakaran } \\
\text { a. Ketidaktersediaan prasarana proteksi } \\
\quad \text { kebakaran } \\
\text { b. Ketidaktersediaan sarana proteksi } \\
\quad \text { kebakaran }\end{array}$ & $\begin{array}{l}\text { Jumlah bangunan } r \text { tidak } \\
\text { terlayani prasarana proteksi } \\
\text { kebakaran } \\
\text { Jumlah bangunan } \\
\text { terlayani tidak } \\
\text { kebakaran }\end{array}$ & $565 \mathrm{KK}$ \\
\hline
\end{tabular}

Sumber: PERMEN PU \& Perumahan Rakyat RI tentang pencegahan dan peningkatan kualitas terhadap perumahan kumuh dan permukiman kumuh, 2018 dan hasil survey, 2019

\section{Penilaian Lokasi}

Untuk menentukan skala prioritas penanganan, maka dilakukan penilaian lokasi di kawasan Wuring yang disajikan dalam tabel 3 berikut.

Tabel 3. Penilaian Lokasi

\begin{tabular}{|c|c|c|}
\hline \multicolumn{3}{|c|}{ TABEL FORMULASI PENENTUAN SKALA PRIORITAS PENANGANAN } \\
\hline \multirow[t]{2}{*}{ NILAI } & \multirow[t]{2}{*}{ KETERANGAN } & $\begin{array}{c}\text { LOKASI PERMUKIMAN } \\
\text { KUMUH }\end{array}$ \\
\hline & & KAWASAN WURING \\
\hline \multicolumn{3}{|l|}{ Kondisi Kekumuhan } \\
\hline $60-80$ & Kumuh Berat & $\mathrm{x}$ \\
\hline $38-59$ & Kumuh Sedang & \\
\hline $16-37$ & Kumuh Ringan & \\
\hline \multicolumn{3}{|l|}{ Legalitas Lahan } \\
\hline$(+)$ & Status Lahan Legal & \\
\hline$(-)$ & Status Lahan Tidak Legal & $\mathrm{x}$ \\
\hline \multicolumn{3}{|l|}{ Pertimbangan Lain } \\
\hline $11-15$ & $\begin{array}{l}\text { Pertimbangan Lain } \\
\text { Tinggi }\end{array}$ & \\
\hline $6-10$ & $\begin{array}{l}\text { Pertimbangan Lain } \\
\text { Sedang }\end{array}$ & $\mathrm{x}$ \\
\hline $1-5$ & $\begin{array}{l}\text { Pertimbangan Lain } \\
\text { Rendah }\end{array}$ & \\
\hline \multicolumn{2}{|c|}{ SKALA PRIORITAS PENANGANAN $=$} & A2 \\
\hline
\end{tabular}

Sumber: PERMEN PU \& Perumahan Rakyat RI tentang pencegahan dan peningkatan kualitas terhadap perumahan kumuh dan permukiman kumuh, 2018 dan hasil survey, 2019

Tabel 4. Rangkuman penilaian

\begin{tabular}{|c|c|c|c|c|c|c|c|c|c|c|c|c|c|}
\hline \multirow[b]{2}{*}{ NO } & \multirow[b]{2}{*}{ NAMA LOKASI } & \multirow{2}{*}{$\begin{array}{l}\text { LUAS } \\
\text { (HA) }\end{array}$} & \multicolumn{3}{|c|}{ LINGKUP ADMINISTRATIF } & \multicolumn{2}{|c|}{ KEPENDUDUKAN } & \multicolumn{2}{|c|}{ KEKUMUHAN } & \multicolumn{2}{|c|}{$\begin{array}{l}\text { PERTIMBANGA } \\
\text { N LAIN }\end{array}$} & \multirow{2}{*}{$\begin{array}{c}\text { LEGALITA } \\
\text { S TANAH }\end{array}$} & \multirow[b]{2}{*}{ PRIORITAS } \\
\hline & & & $\mathrm{RT} / \mathrm{RW}$ & KEL. / DESA & $\begin{array}{c}\text { KEC. } \\
\text { /DISTR } \\
\text { IK }\end{array}$ & JUMLAH & $\begin{array}{l}\text { KEPADA } \\
\text { TAN }\end{array}$ & NILAI & TINGKAT & NILAI & TINGKAT & & \\
\hline 1 & $\begin{array}{l}\text { KAWASAN } \\
\text { WURING }\end{array}$ & 14,36 & $\begin{array}{c}\text { RT042- } \\
049 \text { RW } \\
009\end{array}$ & $\begin{array}{c}\text { Kel. } \\
\text { Wolomarang }\end{array}$ & $\begin{array}{l}\text { Alok } \\
\text { Barat }\end{array}$ & 2227 & Tinggi & 62 & TINGGI & 11 & TINGGI & $\begin{array}{l}\text { TIDAK } \\
\text { LEGAL }\end{array}$ & A2 \\
\hline
\end{tabular}

Sumber: PERMEN PU \& Perumahan Rakyat RI tentang pencegahan dan peningkatan kualitas terhadap perumahan kumuh dan permukiman kumuh, 2018 dan hasil survey, 2019 
Berdasarkan penilaian yang telah dilakukan, maka dapat disimpulkan bahwa kawasan Wuring merupakan lokasi kumuh berat dengan pertimbangan lain tingkat tinggi dan status lahan tidak legal.

\section{Kesimpulan}

Berdasarkan penilaian maka dapat disimpulkan bahwa permukiman kumuh pada Kabupaten Sikka, khususnya kawasan Wuring termasuk dalam kategori kumuh berat dengan penilaian tingkat kepadatan penduduk, tingkat kekumuhan (62) dan pertimbangan lain tinggi (11), serta status lahan tidak legal.

Beberapa cara penanganan kawasan permukiman kumuh dapat ditawarkan pada kawasan kumuh Wuring yang termasuk dalam klasifikasi permukiman kumuh tinggi dengan merujuk pada UU no. 4/1999 tentang perumahan dan permukiman, pasal 27 ayat 2, yaitu: (1.) Melakukan peremajaan, dengan cara meningkatkan kualitas kawasan dengan melakukan kegiatan perombakan untuk perubahan yang mendasar dan menata secara keseluruhan kawasan tempat tinggal yang tidak layak ditempati. (2.) Permukiman kembali (resettlement), yaitu upaya menempatkan permukiman pada lokasi yang secara khusus disediakan. Diprioritaskan bagi permukiman yang menempati tanah negara atau rawan bencana. (3.) Land sharing, yaitu melakukan penataan ulang di atas lahan dengan status kepemilikan masyarakat cukup tinggi. Setelah dilakukan penataan masyarakat kembali mendapatkan lahannya sebagaimana yang dimilikinya, dengan mempertimbangkan kebutuhan untuk prasarana umum. Sesuai peruntukan kawasan kumuh dengan status kepemilikan legal/ sah cukup tinggi, tingkat kekumuhan tinggi namun tata letak permukiman semrawut/ tidak berpola. (4.) Land Consolidation (LC), yaitu melakukan penataan ulang pada lahan yang selama ini ditempati masyarakat dengan status kepemilikan lahan illegal atau tidak sah cukup tinggi, tata letak bangunan dan permukiman yang tidak berpola serta pemanfaatan yang beragam, memiliki potensi menjadi kawasan yang lebih fungsional dan strategis serta dimungkinkan adanya mix use. Sesuai karakteristik lokasi di atas, maka pola penanganan permukiman kumuh pada kawasan Wuring menggunakan pola penanganan kuratif (penanggulangan).

\section{Daftar Pustaka}

Badan Pusat Statistik Kabupaten Sikka. (2019). Kabupaten Sikka dalam angka. Maumere: BPS Kabupaten Sikka.

Departemen Pekerjaan Umum. (2018). Peraturan Menteri Pekerjaan Umum dan Perumahan Rakyat Republik Indonesia no. 14/PRT/M/2018 tentang pencegahan dan peningkatan kualitas terhadap perumahan kumuh dan permukiman kumuh. Jakarta: Departemen Pekerjaan Umum RI.

Direktorat Pengembangan Permukiman, Direktorat Jenderal Cipta Karya, Departemen Pekerjaan Umum. (2006). Pedoman identifikasi kawasan permukiman kumuh penyangga kota metropolitan. Jakarta: Departemen Pekerjaan Umum RI.

Kementrian Perumahan Rakyat. (2012). Penanganan lingkungan perumahan dan permukiman kumuh berbasis kawasan (PLP2K-BK). Jakarta: Kementrian Perumahan Rakyat RI.

Republik Indonesia. (2011). UU no. 1/ 2011 tentang perumahan dan kawasan permukiman. Jakarta: Lembaran Negara RI.

Republik Indonesia. (1999). UU no. 4/ 1999 tentang perumahan dan permukiman pasal 27 ayat 2. Jakarta: Lembaran Negara RI. 